\title{
Detection of Lipase Production from Newly Isolated Trichoderma Citrinoviride
}

\section{Yeni İzole Ediilmiş Trichoderma Citrinoviride'den Lipaz Üretiminin Saptanması}

\author{
Research Article
}

Muhammed Hasan Akyıl* and Nilüfer Cihangir

Hacettepe University Department of Biology, Faculty of Science, Beytepe, Ankara, Turkey.

\section{ABSTRACT}

\begin{abstract}
The production of lipase is aimed from a new fungal source in this study. Fungus was isolated from soil locality Kocaeli. It was determined as Trichoderma citrinoviride by the analysis of 18S rRNA sequence. Various parameters and media components were investigated for production of lipase. Glucose and peptone were found to be most suitable carbon and nitrogen source, respectively. To determine the suitable oil as carbon source, various oils were added to the production medium. Olive oil was found to be the optimal oil for lipase production from Trichoderma citrinoviride. $\mathrm{pH} 5.5$, temperature $30^{\circ} \mathrm{C}$ and incubation time for 4 days were found to be optimal incubation conditions for lipase production. We also determined lipase yield from Trichoderma citrinoviride which is produced in molasses medium as an alternative carbon source.
\end{abstract}

\section{Key Words}

Lipase, Trichoderma citrinoviride, microbial lipase production.

\section{öz}

u çalışmada yeni izole edilmiş bir fungustan lipaz üretimi amaçlanmıştır. Fungus Kocaeli bölgesinden topraktan izole edilmiştir. 18S rRNA analizi sonucu Trichoderma citrinoviride olarak saptanmıştır. Lipaz üretimi için çeşitli parametreler ve besiyeri bileşenleri araştırılmıştır. Sırasıyla, glikoz ve pepton en uygun karbon ve azot kaynağı olarak bulunmuştur. Karbon kaynağı olarak uygun yağı tespit edilmesi için, üretim ortamına çeşitli yağlar eklenmiştir. Zeytinyağının Trichoderma citrinoviride'den lipaz üretimi için en uygun yağ olduğu bulunmuştur. pH 5.5, sıcaklık $30^{\circ} \mathrm{C}$ ve 4 günlük inkübasyon süresi lipaz üretimi için en uygun inkübasyon koşulları olarak bulunmuştur. Alternative karbon kaynağı olarak melas ortamında üretilen Trichoderma citrinoviride'den lipaz verimi de tespit edilmiştir.

\section{Anahtar Kelimeler}

Lipaz, Trichoderma citrinoviride, mikrobiyal lipaz üretimi.

Article History: Received: Jan 16, 2018; Revised: Feb 09, 2018; Accepted: Feb 22, 2018; Available Online: Mar $26,2018$. DOI: $10.15671 /$ HJBC.2018.231

Correspondence to: M.H. Akyıl, Hacettepe University Department of Biology, Faculty of Science, Beytepe, Ankara, Turkey. 


\section{INTRODUCTION}

- nzymes are defined as biological catalysts - that accelerate chemical reactions and allow the maintenance of biological activity, also can be used repeatedly [1]. More before enzymes described they were used in food and textile production [2]. The commercially most widely used enzymes are carbohydrases, proteases and lipases [3]. Lipases (triacylglycerol acylhydrolases, EC. 3.1.1.3) catalyze hydrolysis of triacylglycerol to free fatty acids and glycerol [4]. The use of lipases is becoming more popular in food industry pharmaceutical industry and in cleaning products [5]. Also biodiesel can be synthesized via lipasecatalyzed transesterification $[6,7]$.

It is possible to produce lipase enzyme from fungi that isolated from; oil contaminated soils, waste oils from plants, dairy industry, seeds and perishable food [5]. Lipase production from different fungal sources is possible; Aspergillus, Rhizopus, Mucor, Penicillium, Geotrichumand and Trichoderma [7-9].

Trichoderma is a fungus that has a filament structure, grows very rapidly and can found in any kind of soil, manure or rotting plants. Because of its competitive structure, Trichoderma is predominantly concentrated in the soil. Trichoderma frequently isolated from forest and agricultural soil. Also such as many plant pathogens fungi lives on decaying organic material [8,10-12].

In recent years assessment of waste from the sugar factory, have an important place in lipase production studies. Molasses occurs during the processing of sugar beet to obtain a dark brown colloidal effluent. It is a dark brown colloidal waste. $4 \mathrm{~kg}$ molasses occurs in every $100 \mathrm{~kg}$ of processed sugar beet [13].

Various studies show that Ülker and colleagues produced extracellular lipase from Trichoderma harzianum, Kashmiri et.al. isolated lipase from Trichoderma viride and Krastanov et.al. isolated laccase from Trichoderma longibrachiatum $[8,14,15]$.

In this paper describes for the first time, the characterization of a novel extracellular lipase from Trichoderma citrinoviride that isolated from soil in ilimtepe/Kocaeli, Turkey.

\section{MATERIALS and METHODS}

In this study Trichoderma citrinoviride that isolated from soil (ilimtepe/ Kocaeli/Turkey) was used for lipase source. After isolation Bioeks Medical and Biotechnology Research Systems isolated DNA accordance with the protocol by Bioseepdy DNA isolation $\mathrm{kit}^{\circledR}$ and $18 \mathrm{~S}$ rRNA sequence analysis has determined the fungi as Trichoderma citrinoviride. The microorganism matched with Trichoderma citrinoviride(accession number: EU280098.1, 99\%).

To determination lipolytic activity, inoculated on tributyrin agar ( $1 \%$ agar, $0.5 \%$ peptone, $3 \%$ yeast extract) Many researchers have used tributyrin agar for determination microorganisms lipolytic activity. The microorganisms that having lipase enzyme, create a zone while during reproduction [16-18].

\section{Lipase Production Medium}

After the determination of the lipase enzyme the organism was cultured in $100 \mathrm{~mL}$ of basal mineral medium that Hatzinikolau et.al. described [19]: ((g/L): $12 \mathrm{NaH}_{2} \mathrm{PO}_{4}, 2 \quad \mathrm{KH}_{2} \mathrm{PO}_{4}, 0.330 \mathrm{CaCl}_{2} .2 \mathrm{H}_{2}$ $\mathrm{O}, 0.030 \mathrm{ZnSO}_{4} \cdot 7 \mathrm{H}_{2} \mathrm{O}, 0.030 \mathrm{MgSO}_{4} .7 \mathrm{H}_{2} \mathrm{O}, 0.005$ $\mathrm{FeSO}_{4} \cdot 7 \mathrm{H}_{2} \mathrm{O}$ ), and $1 \mathrm{ml}$ olive oil added as a carbon source, in a $250 \mathrm{~mL}$ conical flask shaken at 150 rpm at $30^{\circ} \mathrm{C}$ and $\mathrm{pH}$ setted to 5.5 .

\section{Determination of Growth Curve}

To determinate Trichoderma citrinoviride growth curve we inoculated it in lipase production medium for ten days. Each day lipase production medium media was filtered through pre-weighted filter paper (Whatman No. 1) to extract the biomass. Thus measuring the dry weight the growth curve occurred.

\section{Lipase Activity Assay}

The filtrate of the lipase production medium used for enzyme source. Titrimetric assay performed for measuring the lipolytic activity as Sugihara described [20].

$1 \mathrm{ml}$ olive oil, $4.5 \mathrm{ml} 50 \mathrm{mM}$ acetate buffer $0.1 \mathrm{ml}$ $0,5 \mathrm{M} \mathrm{CaCl}_{2}$ and $1 \mathrm{ml}$ filtrate has added for incubation area. Distilled water was added instead of filtrate to prepare blind tube. After 30 minutes incubation time, $20 \mathrm{ml}$ of ethanol added for reaction stop. After this step both $50 \mathrm{mM} \mathrm{KOH}$ tube was added until the 
$\mathrm{pH}$ rises to 10.5. After titration, amount of expended $\mathrm{KOH}$ formulated to calculate lipase activity,

$(50 x$ expended $\mathrm{KOH}) /(30$ (incubation time $))=\mathrm{U} / \mathrm{ml}$

Special activity was calculated by dividing the lipase activity to dry weight.

\section{Determination of the Optimal Incubation Time pH and Temperature}

Trichoderma citrinoviride inoculated in lipase production medium and incubated it for ten days. Each day lipase activity measured to find optimal incubation time. To find out optimal $\mathrm{pH}$ and temperature, lipase production medium was setted between $\mathrm{pH}$ 3-9 and incubation temperature was setted between $10-40^{\circ} \mathrm{C}$.

\section{Effect of Carbon and Nitrogen Source}

Sunflower oil, soybean oil, corn oil and hazelnut oil were used as carbon source instead of olive oil. In addition, it added various carbon sources were added to lipase production medium; glucose, galactose, fructose, lactose, maltose and sucrose. After this step, added optimal oil and sugar source to detect together effects.

To determinate optimal nitrogen source in addition to peptone, we added ammonium sulfate, urea, yeast extract, casein, ammonium oxalate, ammonium nitrate, ammonium carbonate and proteose peptone, described by Sugihara and colleagues [20].

\section{Lipase Production in Molasses Medium}

The cost of production media for lipase production and to evaluate this food industrial waste, Trichoderma citrinoviride was inoculated in media that include only molasses. To examine the effect of molasses to lipase production, we diluted molasses in different proportions. Accordingly, the total molasses rate is prepared to $1 \%, 2 \%$, $3 \%, 4 \%$ and $5 \% .1 \mathrm{ml}$ of our culture inoculated in production media. Lipase activity and optimal molassesration were determined after incubation.

\section{RESULTS and DISCUSSION}

After ten days incubation, and each day measuring the dry weight, growth curve occurred. (Figure1). In first five days Trichoderma citrinoviride grown increasingly, after then grow has been decreased.

\section{Optimal Incubation Time, $\mathrm{pH}$ and Temperature} After ten days incubation and measuring lipase activity we determined highest activity on 4th day, after then lipase activity started to decrease. Thence in this study optimal incubation time was regarded as 4th day (Figure 2 ). And remaining study incubated for 4 days.

The effect of hydrogen ion concentration of production medium for lipase activity of Trichoderma citrinoviride was studied. At $\mathrm{pH} 5$ lipase activity measured $9.29 \mathrm{U} / \mathrm{ml}$, and at pH 6 it measured $8.13 \mathrm{U} / \mathrm{ml}$. These values is the highest rates in different $\mathrm{pH}$ levels. When we compare the

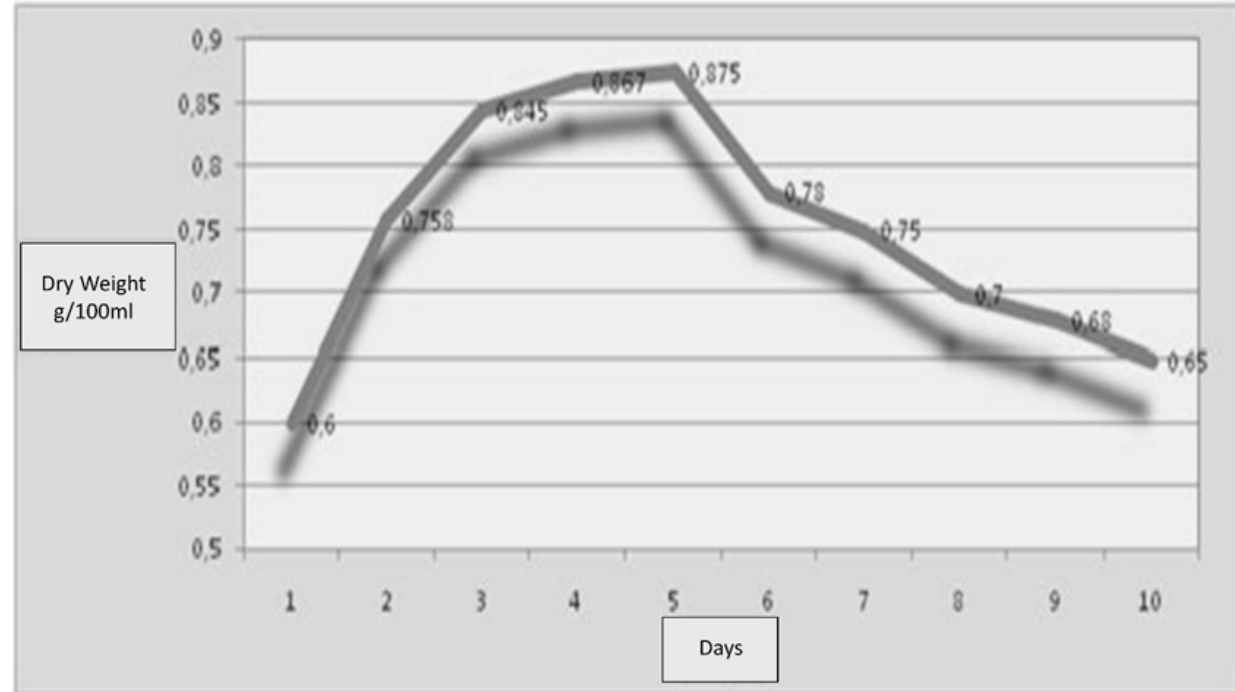

Figure 1.Trichoderma citrinoviride growth curve. 


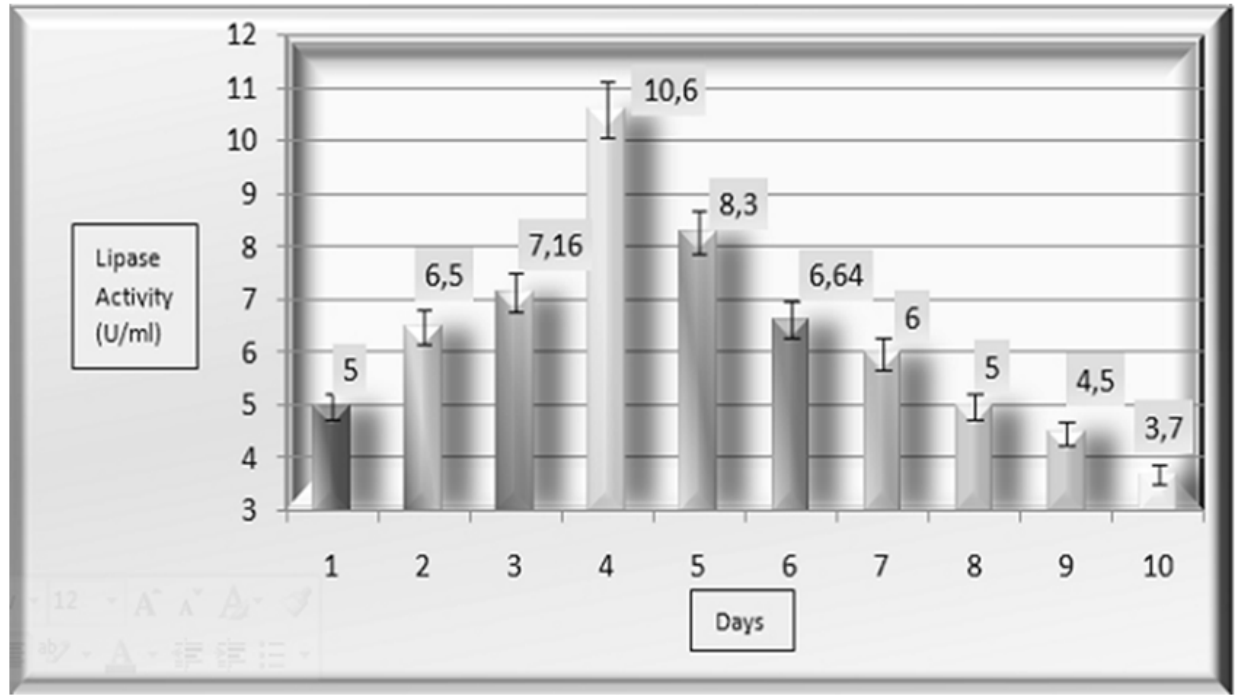

Figure 2. Effect of incubation time on lipase activity.

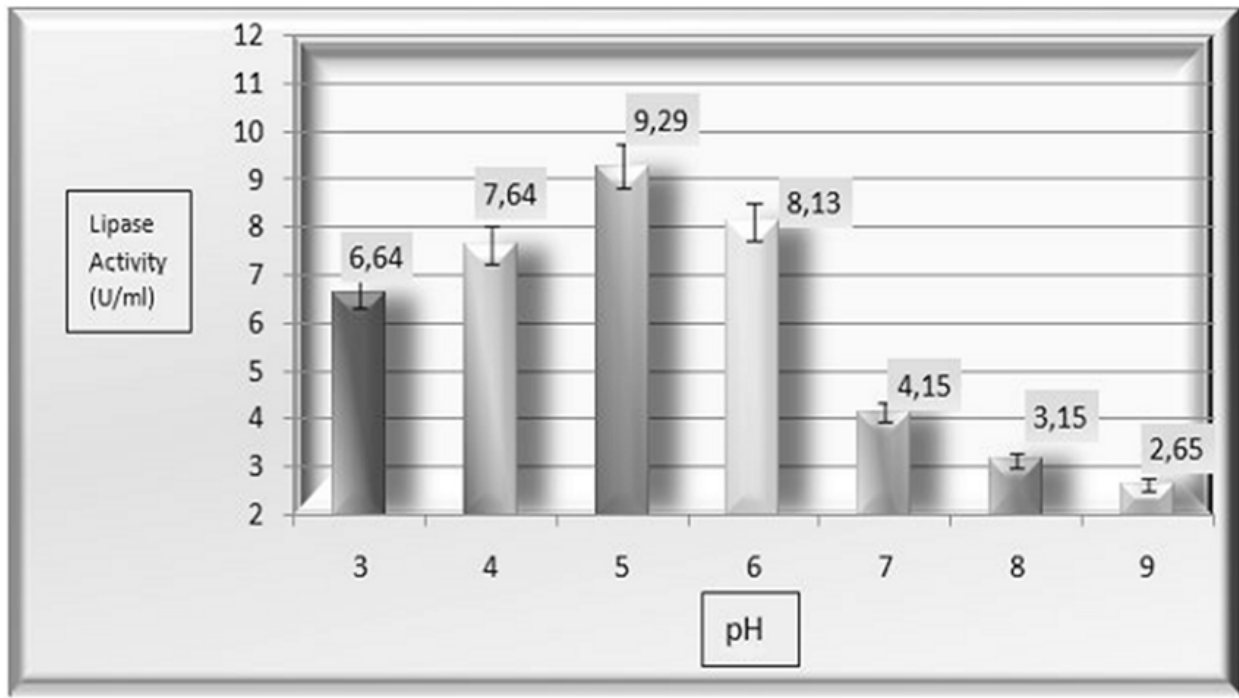

Figure 3. Effect of $\mathrm{pH}$ on lipase activity.

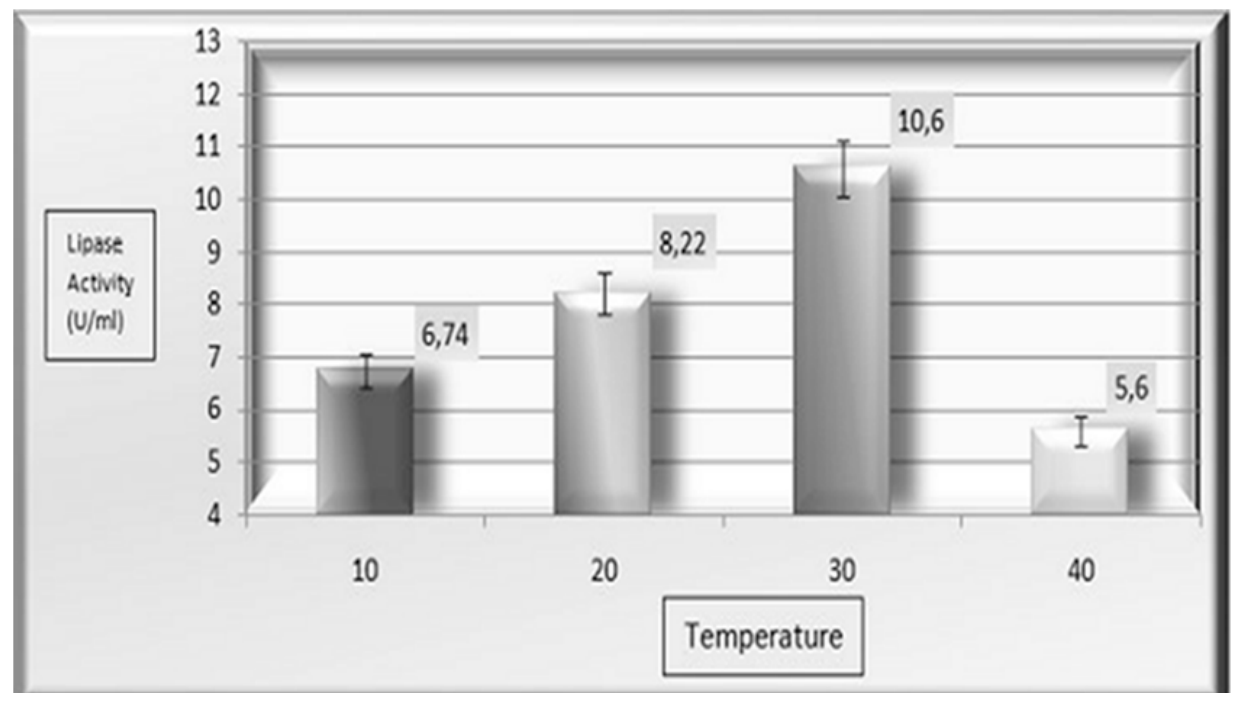

Figure 4. Effect of temperature on lipase activity. 
results with the beginning conditions we saw that $\mathrm{pH} 5.5(10.6 \mathrm{U} / \mathrm{ml})$ is the optimum $\mathrm{pH}$ for lipase production from Trichoderma citrinoviride (Figure 3). And optimum temperature for lipase production was founded as $30^{\circ} \mathrm{C}$ (Figure 4).

Highest activity was observed in the medium that includes olive oil, and we found out that lowest lipase activity is in the medium that includes corn oil (Fig. 5). We also detected that glucose is most suitable carbon source(Figure 6) and peptone is most suitable nitrogen source for lipase activity from Trichoderma citrinoviride (Figure 7).
Finally we detected lipase activity under the optimum conditions we determined for lipase activity (Carbone source glucose, and olive oil, nitrogen source: peptone, $\mathrm{pH}$ : 5.5, temperature: $30^{\circ} \mathrm{C}$ ). The activity was detected $13.68 \mathrm{U} / \mathrm{ml}$. (Figure $8)$.

We determined the highest lipase activity at 4 th day of the incubation. We compare our results with other studies; Kashmiri et.al. detected that 50 hours is optimum incubation time for Trichoderma viride in their study [14]. Açıkel et al. find out optimum incubation time is 5 day for Rhizopus

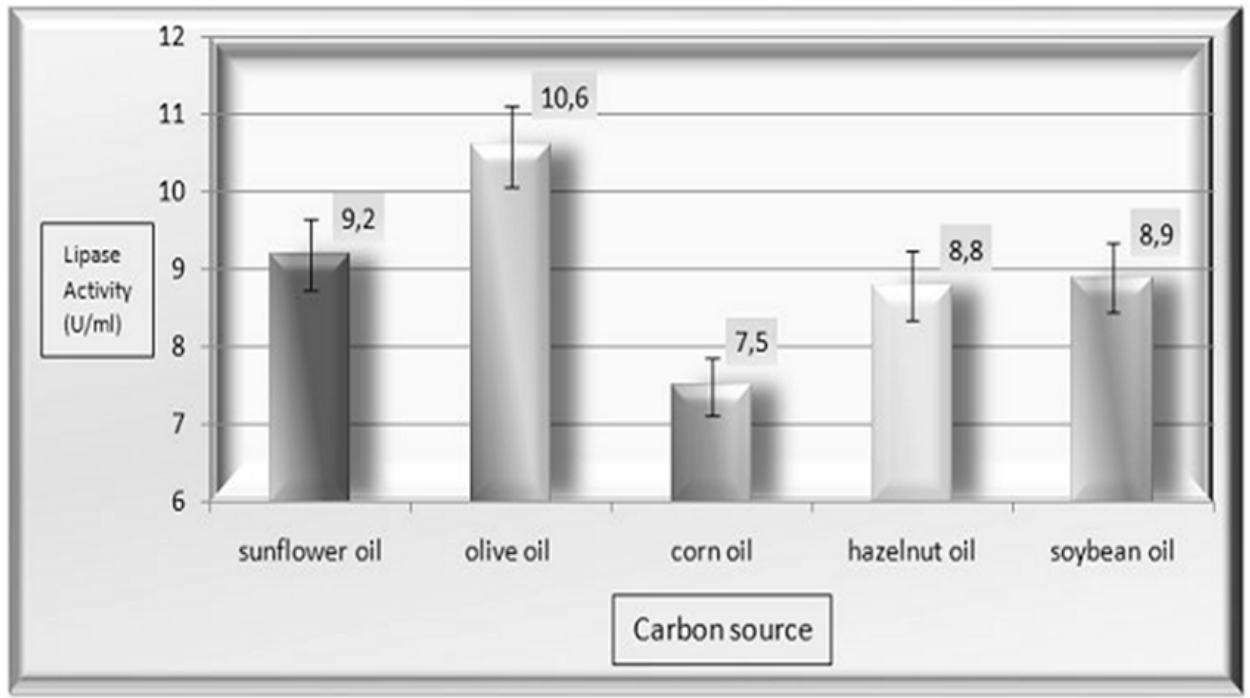

Figure 5. Effect of carbon source (oil varieties) on lipase activity.

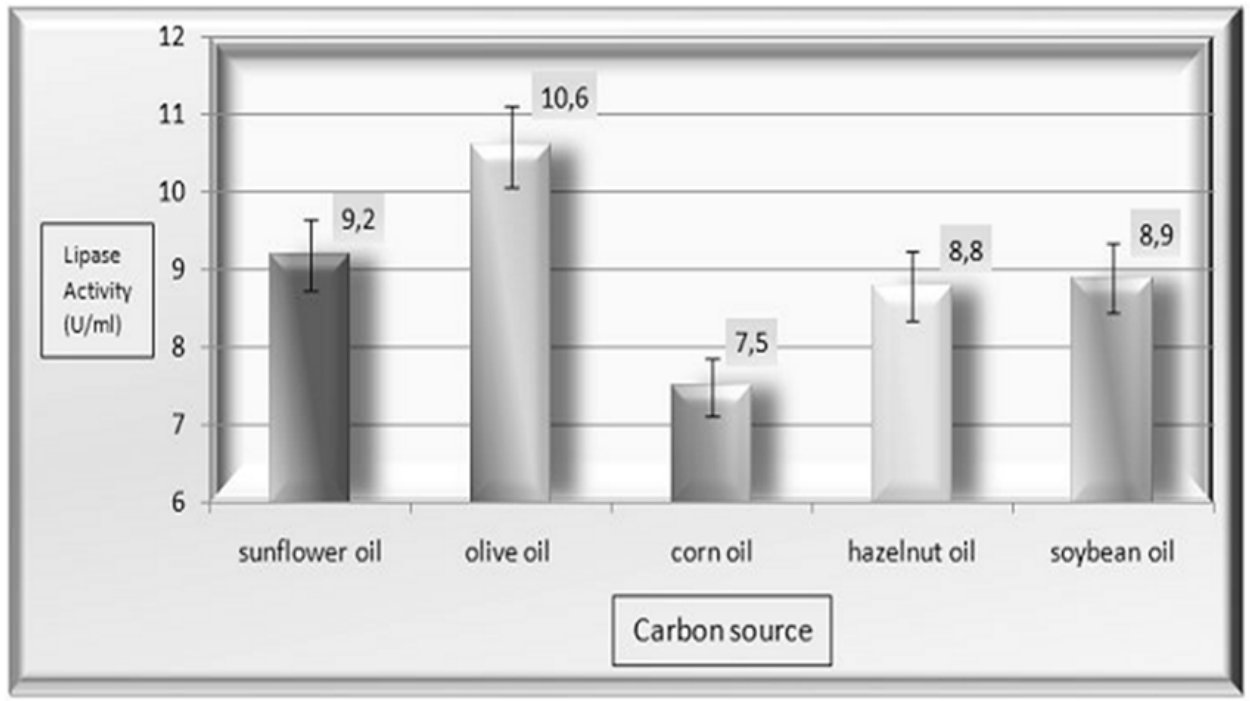

Figure 6. Effect of carbon source (sugar varieties) on lipase activity. 


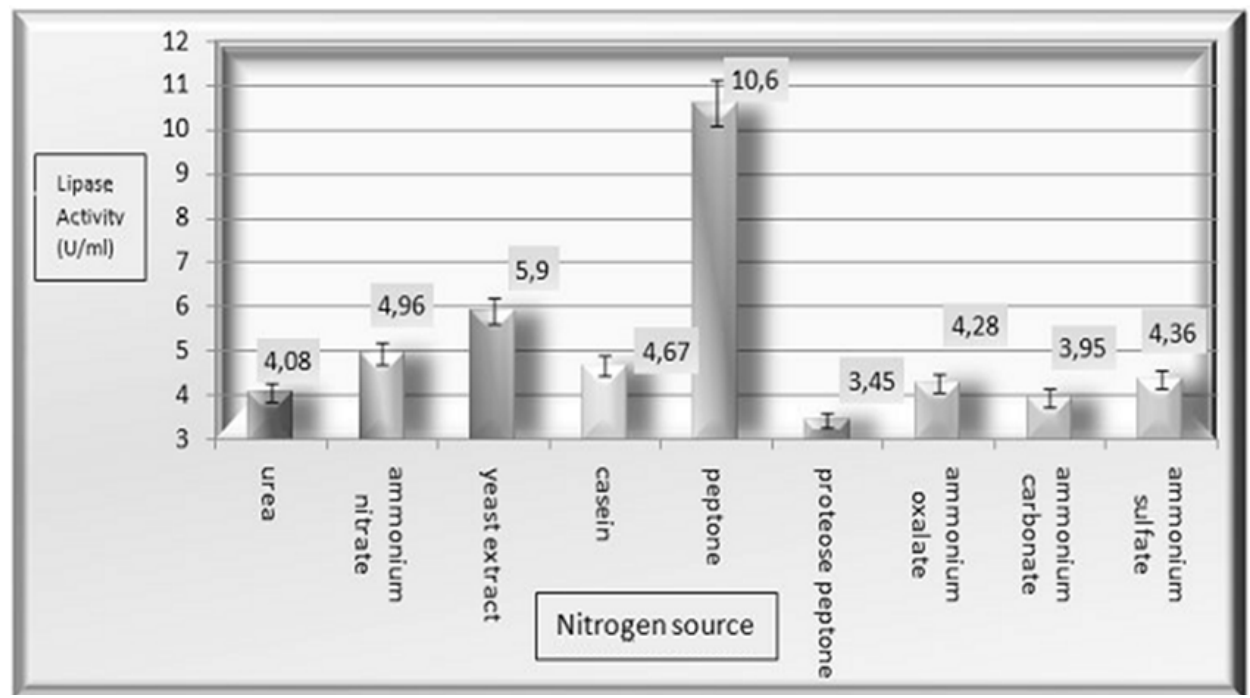

Figure 7. Effect of nitrogen source on lipase activity.

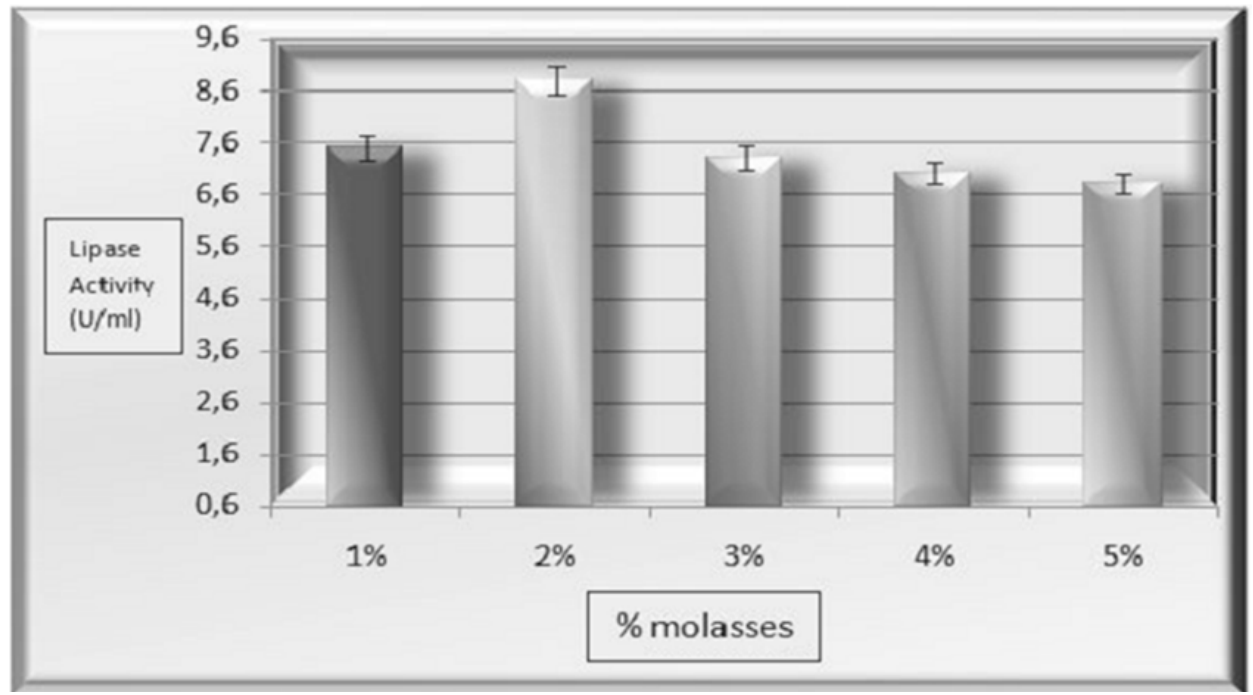

Figure 8. Lipase activity in molasses medium.

delemar [21], Ulker et al. detected the 7th day is optimum incubation time for lipase activity from Trichoderma harziamum [8].Optimum lipase activity was determined at $\mathrm{pH} 5$. Decrease was observed at lipase activity in alkaline $\mathrm{pH}$, acidic $\mathrm{pH}$ is more suitable for Trichoderma citrinoviride lipase activity. Kumar et.al. find out the optimum $\mathrm{pH}$ 8.5, for al alkaliphilic Bacillus coagulans [22].

Optimum incubation temperature was founded $30^{\circ} \mathrm{C}$. Considering the cleaning industry; optimum $30^{\circ} \mathrm{C}$ for lipase activity is very useful especially in terms of energy saving. In lower temperature $\left(10-20^{\circ} \mathrm{C}\right)$ despite the reduction, the activity was observed substantially. Especially in detergent formulation cold active lipase is used for cold washing also reduces the wear and tear of textile fibers. Toscano et.al. determined that Trichoderma harzianum lipase activity had started to decrease after $50^{\circ} \mathrm{C}[23]$.

The oils that added to the growth medium have not any direct effect on Trichoderma citrinoviride reproduction. But it is observed that there is a significant effect on lipase activity.The growth medium that added olive oil as carbon source 
showed the highest lipase activity. Sunflower oil hazelnut oil and soybean oil has showed close activity. The medium with corn oil as carbon source was showed the lowest activity. We also found out that glucose is most suitable carbon source for lipase activity from Trichoderma citrinoviride. And galactose is not convenient for lipase production. Peptone was found to have a remarkable effect on lipase activity. Various nitrogen sources except peptone, caused a decrease in lipase activity.

There has been shown slightly decline of lipase activity after using molasses for production Trichoderma citrinoviride. But when considering the costs, it was concluded that molasses can be used for Trichoderma production.

\section{References}

1. P.K. Robinson, Enzymes: principles and biotechnological applications, Essays Biochem., 59 (2015) 1-41.

2. E.R. Riegel J.A. Kent, Kent and Riegel's Handbook of Industrial Chemistry and Biotechnology, Ebook, (2007) 1-1833.

3. Ö.E. Kiran, U. Çömlekçioğlu, N. Dostbil, Bazı Mikrobiyal Enzimler ve Endüstrideki Kullanım Alanları, Fen ve Mühendislik Derg., 9 (2006) 12-19.

4. F. Ferrato, F. Carriere, L. Sarda, R. Verger, A critical reevaluation of the phenomenon of interfacial activation, Methods Enzymol., 286 (1997) 327-347.

5. A. K. Singh, M. Mukhopadhyay, Overview of fungal lipase: a review., Appl. Biochem. Biotechnol., 166 (2012) 486-520.

6. P.S. Bisen, B.S. Sanodiya, G.S. Thakur, R.K. Baghel, G.B.K.S. Prasad, Biodiesel production with special emphasis on lipase-catalyzed transesterification Biotechnol. Lett., 32 (2010) 1019-1030.

7. X. Zhao, F. Qi, C. Yuan, W. Du, and D. Liu, Lipasecatalyzed process for biodiesel production: Enzyme immobilization, process simulation and optimization, Renew. Sustain. Energy Rev., 44 (2015)182-197.

8. S. Ülker, A. Özel, A. Çolak, Ş.A. Karaoğlu, Isolation, production, and characterization of an extracellular lipase from Trichoderma harzianum isolated from soil, Turk. J. Biol., 35 (2011) 543-550.

9. H. Musa, P.C. Han, F.H. Kasim, S.C.B. Gopinath, M.A. Ahmad, Turning oil palm empty fruit bunch waste into substrate for optimal lipase secretion on solid state fermentation by Trichoderma strains, Process Biochem., 63 (2017) 35-41.

10. T. Andrade Marques, C. Baldo, D. Borsato, J. Batista Buzato, M. Antonia Pedrine Colabone Celligoi, Production And Partial Characterization of a Thermostable, Alkaline And Organic Solvent Tolerant Lipase From Trichoderma atroviride 676, Int. J. Sci. Technol. Res., (2014) 5
11. K. Kuhls, E. Lieckfeldt, T. Borner, E. Gueho, Molecular reidentification of human pathogenic Trichoderma isolates as Trichoderma Iongibrachiatum and Trichoderma citrinoviride., Med. Mycol., 37 (1999) 25-33.

12. G. J. Samuels, Trichoderma: a review of biology and systematics of the genus, Mycol. Res., 100 (1996) 923-935.

13. M. Kahyao, Ğ. Lu, V. Konar, Şeker Fabrikası Atık Maddeleri Kullanılarak Pseudomonas aeruginosa'dan Ramnolipit Biyosürfektan Elde Edilmesi, 18 (2006) 493-498.

14. M.A. Kashmiri, A. Adnan, B. W. Butt, Production, purification and partial characterization of lipase from Trichoderma viride, African J. Biotechnol., 5 (2006) 878-882.

15. A.I. Krastanov, V.K. Gochev, T.D. Girova, Nutritive medium dependent biosynthesis of extracellular laccase from Trichoderma spp., Bulg. J. Agric. Sci., 13 (2007) 349-355.

16. D. Kumar, L. Kumar, S. Nagar, C. Raina, R. Parshad, V.K. Gupta, Screening, isolation and production of lipase/ esterase producing Bacillus sp. strain DVL2 and its potential evaluation in esterification and resolution reactions, Arch. Appl. Sci. Res., 4 (2012) 1763-1770.

17. E. Sirisha, N. Rajasekar, M.L. Narasu, Isolation and optimization of lipase producing bacteria from oil contaminated soils, Adv. sin Biol. Res., 4 (2010) 249252.

18. M.Y. a. Samad, C.N. a. Razak, A.B. Salleh, W.M. Zin Wan Yunus, K. Ampon, and M. Basri, A plate assay for primary screening of lipase activity, J. Microbiol. Meth., 9 (1989) 51-56.

19. D.G. Hatzinikolaou, J.B. Macris, P. Christakopoulos, D. Kekos, F.N. Kolisis, G. Fountoukidis, Production and partial characterisation of extracellular lipase from Aspergillus niger, Biotechnol. Lett. 18 (1996) 547-552.

20. A. Sugihara, T. Tani, Y. Tominaga, Purification and characterization of a novel thermostable lipase from Bacillus sp., J. Biochem., 109 (1991) 211-216.

21. U. Açıkel and M. Erşan, Acid phosphatase production by Rhizopus delemar: a role played in the $\mathrm{Ni}(\mathrm{II})$ bioaccumulation process, J. Hazardous Materials, 184 (2010) 1-3.

22. S. Kumar, K. Kikon, A. Upadhyay, S.S. Kanwar, R. Gupta, Production, purification, and characterization of lipase from thermophilic and alkaliphilic Bacillus coagulans BTS-3, Protein Expr. Purif., 41 (2005) 3844.

23. L. Toscano, G. Montero, L. Cervantes, M. Stoytcheva, V. Gochev, and M. Beltrán, Production and partial characterization of extracellular lipase from Trichoderma harzianum by solid-state fermentation, Biotechnol. Biotechnol. Equip., 27 (2013)3776-3781 